\title{
Article \\ Identification and Characterization of the Masculinizing Function of the Helicoverpa armigera Masc Gene
}

\author{
Zhongyuan Deng ${ }^{1}{ }^{\circledR}$, Yakun Zhang $^{2}$, Yalu Li ${ }^{1}$, Kaiyuan Huang ${ }^{1}$, Xuewei Chen ${ }^{1}$, Min Zhang ${ }^{1}$, Jinyong Huang ${ }^{1}$, \\ Xinzhi $\mathrm{Ni}^{3}$ and Xianchun $\mathrm{Li}^{4, *(1)}$ \\ 1 School of Agricultural Sciences, Zhengzhou University, Zhengzhou 450001, China; \\ dengzhongyuan@outlook.com (Z.D.); pirna@foxmail.com (Y.L.); aauaaa@foxmail.com (K.H.); \\ chen_xw@zzu.edu.cn (X.C.); zhangmin753@gmail.com (M.Z.); jinyhuang@zzu.edu.cn (J.H.) \\ 2 State Key Laboratory for Biology of Plant Diseases and Insect Pests, Institute of Plant Protection, Chinese \\ Academy of Agricultural Sciences, Beijing 100193, China; zhangyakun7@bjfu.edu.cn \\ 3 Crop Genetics and Breeding Research Unit, USDA-ARS (United States Department of \\ Agriculture-Agricultural Research Service), Tifton, GA 31793, USA; xinzhi.ni@usda.gov \\ 4 Department of Entomology, University of Arizona, Tucson, AZ 85721, USA \\ * Correspondence: 1xc@email.arizona.edu; Fax: +1-(520)-621-1150
}

Citation: Deng, Z.; Zhang, Y.; Li, Y.; Huang, K.; Chen, X.; Zhang, M.; Huang, J.; Ni, X.; Li, X. Identification and Characterization of the

Masculinizing Function of the Helicoverpa armigera Masc Gene. Int. J. Mol. Sci. 2021, 22, 8650. https:// doi.org/10.3390/ijms22168650

Academic Editors:

Jadwiga Jaruzelska,

Kamila Kusz-Zamelczyk and

Silvano Bertelloni

Received: 29 June 2021

Accepted: 9 August 2021

Published: 11 August 2021

Publisher's Note: MDPI stays neutral with regard to jurisdictional claims in published maps and institutional affiliations.

Copyright: (c) 2021 by the authors. Licensee MDPI, Basel, Switzerland. This article is an open access article distributed under the terms and conditions of the Creative Commons Attribution (CC BY) license (https:/ creativecommons.org/licenses/by/ $4.0 /)$

\begin{abstract}
The Masculinizer (Masc) gene has been known to control sex development and dosage compensation in lepidopterans. However, it remains unclear whether its ortholog exists and plays the same roles in distantly related lepidopterans such as Helicoverpa armigera. To address this question, we cloned Masc from H. armigera (HaMasc), which contains all essential functional domains of BmMasc, albeit with less than 30\% amino acid sequence identity with BmMasc. Genomic PCR and qPCR analyses showed that HaMasc is a $\mathrm{Z}$ chromosome-linked gene since its genomic content in males (ZZ) was two times greater than that in females (ZW). RT-PCR and RT-qPCR analyses revealed that HaMasc expression was sex- and stage-biased, with significantly more transcripts in males and eggs than in females and other stages. Transfection of a mixture of three siRNAs of HaMasc into a male embryonic cell line of $H$. armigera led to the appearance of female-specific mRNA splicing isoforms of $H$. armigera doublesex (Hadsx), a downstream target gene of HaMasc in the H. armigera sex determination pathway. The knockdown of HaMasc, starting from the third instar larvae resulted in a shift of Hads $x$ splicing from male to female isoforms, smaller male pupa and testes, fewer but larger/longer spermatocytes and sperm bundles, delayed pupation and internal fusion of the testes and follicles. These data demonstrate that HaMasc functions as a masculinizing gene in the H. armigera sex-determination cascade.
\end{abstract}

Keywords: chromosome; development; doublesex; sex determination; sperm bundle; testis fusion

\section{Introduction}

The sex of an individual insect is determined genetically upon fertilization and developmentally upon embryogenesis [1-3]. The developmental determination of sex is regulated by a cascade of genes that act upon one another to form the sex-determination pathway in a given insect species [1-4]. The pathway is triggered or initiated by a primary signal derived from the chromosomal makeup of a fertilized egg, such as the $X$ chromosome/autosome ratio in Drosophila melanogaster [5] and the $\mathrm{W}$ chromosome-linked Feminizer piRNA in the Bombyx mori [6]. The primary signal is transduced, often via alternatively splicing, to two terminal double-switch genes known as doublesex ( $d s x)$ and fruitless (fru) that specify the sexual fate of a fertilized egg $[1,4,7,8]$. Between the primary signal and the two terminal switch genes stands a key gene that undertakes a splicing-mediated autoregulatory feedback loop [7]. In the presence or absence of the primary signal, a few alternatively spliced regulatory genes undergo regulated splicing in one sex, and default splicing in the other sex, leading to sex differentiation $[4,7]$. 
Work on the sex determination pathway among different insect species from Diptera, Coleoptera, Hymenoptera, and Lepidoptera support Wilkins's "bottom-up" theory: betweentaxa or species-divergence sequentially elevates from the terminal end to the beginning point of the pathway [7,9]. For example, $d s x$ and fru are the common terminal switch genes in all insects, whereas the upstream key gene is Sex-lethal (Sxl) in Drosophila melanogaster, transformer (tra) in many other dipterans, coleopterans, and hymenopterans, Feminizer (fem) in Apis mellifera, and the IGF-II mRNA-binding protein (BmImp) in Bombyx mori [7]. The most diverse step is the initiating primary signal, which can be a female-determining factor such as a double dose of the X-linked signal elements in D. melanogaster [5], heterozygosity of the complementary sex determiner (csd) gene in honeybees [10], or a W chromosome-linked Piwi-interacting RNA (piRNA), named Feminizer piRNA (Fem piRNA), in B. mori [6]. In contrast, the primary signal can also be a dominant male-determining factor ( $\mathrm{M}$ factor) located on a Y chromosome or a homomorphic sex-determining chromosome in many other species, including mosquitoes, non-Drosophila flies, beetles, and true bugs [11-15]. Among the identified M factors are Nix in Aedes aegypti [16], gYG2 (An. gambiae Y Gene 2, renamed Yob) in Anopheles gambiae [17,18], Guy1 in Anopheles stephensi [19], Mdmd in Musca domestica [20], and MoY in Ceratitis capitata [21]. These M factors are not related to each other, indicating rapid evolution of the primary signals [8].

Relatively much less is known about the sex-determination pathway in the $\mathrm{ZW}$ order Lepidoptera. In contrast to $X Y$ insects, in Lepidoptera, males are homogametic (ZZ), and females are heterogametic (ZW) [22,23]. Almost all information about sex-determination cascade in this order comes from studies in the model lepidopteran B. mori. An aspect of the uniqueness of the B. mori sex-determination cascade is that it has both Fem piRNA, a female determinant from the $\mathrm{W}$ chromosome, and Masculinizer (Masc), a male determinant from the $\mathrm{Z}$ chromosome $[6,24]$. The absence of the $\mathrm{W}$ chromosome, and thus, of the primary signal Fem piRNA in males permits B. mori Masc (BmMasc) to induce male-specific splicing of BmImp, the autoregulatory key gene [25]. The resultant male isoform of BmImp interacts with the B. mori P-element somatic inhibitor (BmPSI), and possibly, BmSPX as well, to stimulate male-specific splicing of $B m d s x$ [4,26-28]. In contrast, the presence of the primary signal Fem piRNA in females leads to the default female-specific splicing of $B m d s x$ because a complex of Fem piRNA with BmPIWI (= BmSIWI) and BmAsh2 [29] target BmMasc mRNA for degradation to a much lower level, which is insufficient to induce the regulated male-specific splicing of BmImp and then Bmdsx [6].

The question to be addressed here is whether a homolog of BmMasc exists and plays the same role in the distantly related Helicoverpa armigera, a noctuid lepidopteran of economic importance. We initiated this study by a BLAST search of an H. armigera larvae transcriptome, followed by the PCR cloning of the full-length cDNA sequence of HaMasc (the H. armigera homolog of BmMasc), quantitative PCR (qPCR) analysis of HaMasc copies, RT-qPCR (quantitative reverse transcriptase-PCR) analysis of HaMasc expression, and the RNAi (RNA interference) knockdown of HaMasc. The findings from this study demonstrate that HaMasc, like BmMasc, is a Z chromosome-linked male determinant required for the regulated male-specific splicing of $d s x$ and the normal development of testis.

\section{Results}

\subsection{Cloning and Identification of HaMasc}

Two full-length cDNA sequences of H. armigera homolog of BmMasc (NP_001296506.1), named HaMasc1 (GenBank accession number: MH844486) and HaMasc2 (GenBank accession number: MH844487) (Figure 1A), were obtained by TBLASTN retrieval of the contig asmbl_65189 from an H. armigera transcriptome dataset [30], followed by the RT-PCR cloning of contig asmbl_65189 and the amplification of the $5^{\prime}$ and $3^{\prime}$ ends of HaMasc through $5^{\prime}$ and $3^{\prime}$ RACE. The two cDNA sequences shared a common open reading frame (ORF) of 1896 bp encoding 632 amino acid residues and a common $3^{\prime}$-untranslated region (UTR) of $641 \mathrm{bp}$ but differed in the size of the $5^{\prime}$ UTR (Figure 1A). The mapping and alignment of the two cDNA sequences to their genomic sequence in scaffold 349 of the $H$. 
armigera genome show that the HaMasc gene contains 12 exons and 11 introns (Figure 1B). Exons 1 and 12 belong to HaMasc's 5' UTR and $3^{\prime}$ UTR, respectively, whereas Exons 2-11 compose HaMasc's ORF (Figure 1B). The 5' UTR difference between HaMasc1 and HaMasc2 resulted from the retention of Intron 1 in HaMasc 1 and the absence of the $5^{\prime}-92$ bp sequence of exon 1 in HaMasc2 (Figure 1).

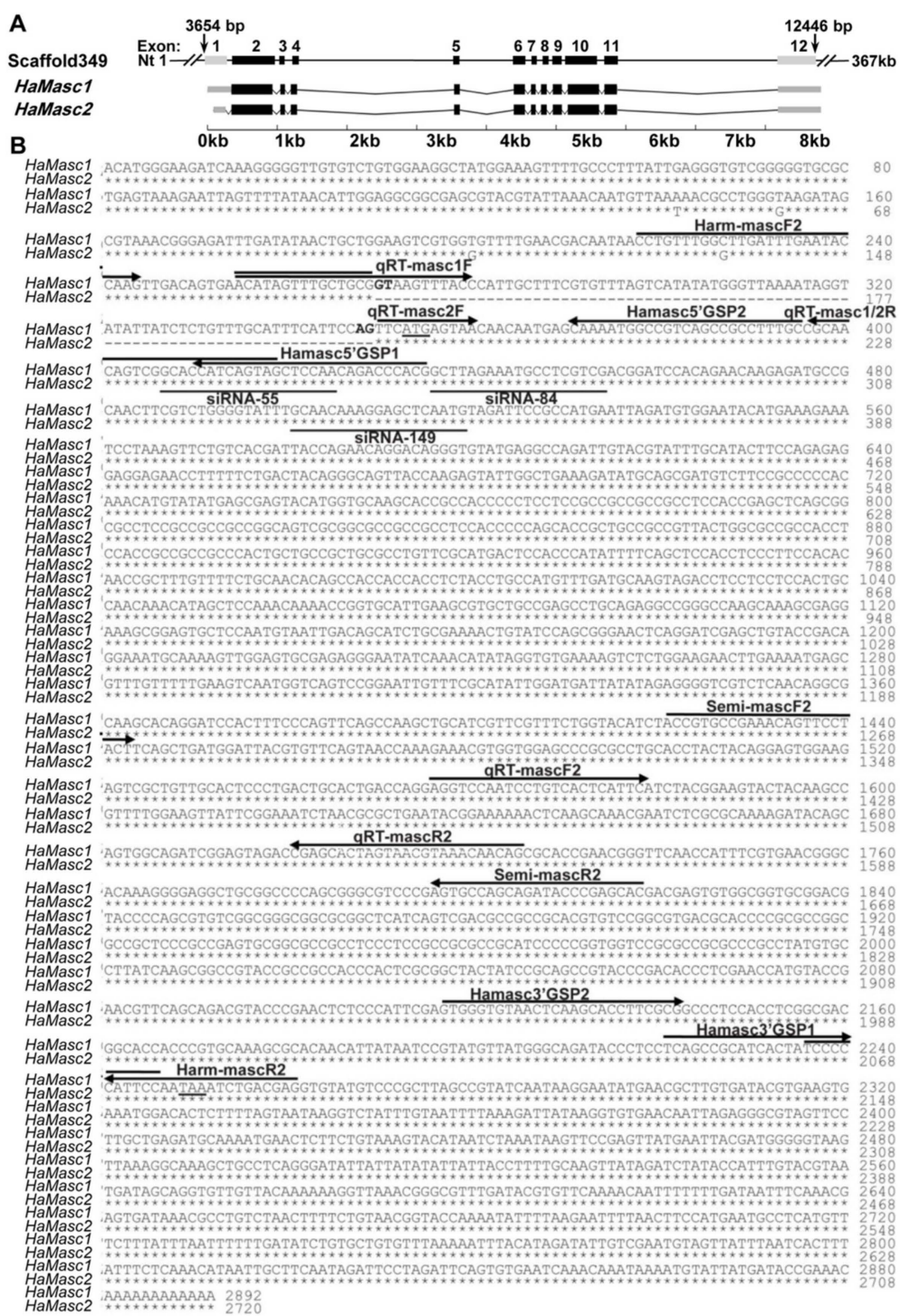

Figure 1. Identification and characterization of HaMasc. (A) Genomic structure of HaMasc gene. Black boxes represent the ten exons for the common ORF of the two HaMasc transcripts. Gray boxes depict the exons for the $5^{\prime}$ and $3^{\prime}$ UTR of the HaMasc transcripts. The spaces between boxes indicate introns. The size of the putative exons and introns is drawn to scale. (B) cDNA nucleotide sequence of HaMasc transcripts. The two transcripts of HaMasc, called HaMasc1 and HaMasc2, are aligned with asterisks $\left(^{*}\right)$ and dashes (-) depicting the conserved nucleotides and indels (insertions/deletions) between the two transcripts, respectively. The start (ATG) and stop (TGA) codons are underlined. The target regions of the three siRNA are indicated by lines and the corresponding siRNA names. The annealing directions and positions of the primers used for the $5^{\prime}$ RACE, $3^{\prime}$ RACE, and full-length cDNA cloning of HaMasc, as well as for RT-PCR and RT-qPCR analyses of HaMasc, are depicted with arrowed lines and the corresponding primer names. When two primers or siRNAs partially anneal to or target the same positions, they have an overlapping line.

While the deduced HaMasc protein shares only a $21.14 \%$ to $62.57 \%$ identity with Masc homologs from T. variants [31], B. mori [6], O. furnacalis [32], A. ipsilon [33], and Plutella 
xylostella [34] (Table 1), HaMasc, like the above Masc proteins, contains two tandem CCCHtype zinc finger domains, one nuclear localization signal (NLS) and one CC masculinization motif (Figure 2), which are essential for the functions of BmMasc [6]. Phylogenetic analysis grouped HaMasc and AiMasc in the same terminal lineage, consistent with the fact that $H$. armigera and A. ipsilon belong to the same family of Noctuidae (Figure 3).

Table 1. Amino acid sequence identity among lepidopteran Masc proteins.

\begin{tabular}{ccccccc}
\hline & BmMASC & TvMASC & OfMASC & AiMASC & HaMASC & PxMASC \\
\hline BmMASC & 100.00 & & & & & \\
TvMASC & 54.99 & 100.00 & & & & \\
OfMASC & 22.48 & 22.29 & 100.00 & & & \\
AiMASC & 21.38 & 19.37 & 30.71 & 100.00 & & \\
HaMASC & 25.00 & 22.52 & 34.01 & 62.57 & 100.00 & 100 \\
PxMASC & 19.74 & 17.01 & 22.30 & 19.76 & 21.14 & 100 \\
\hline
\end{tabular}

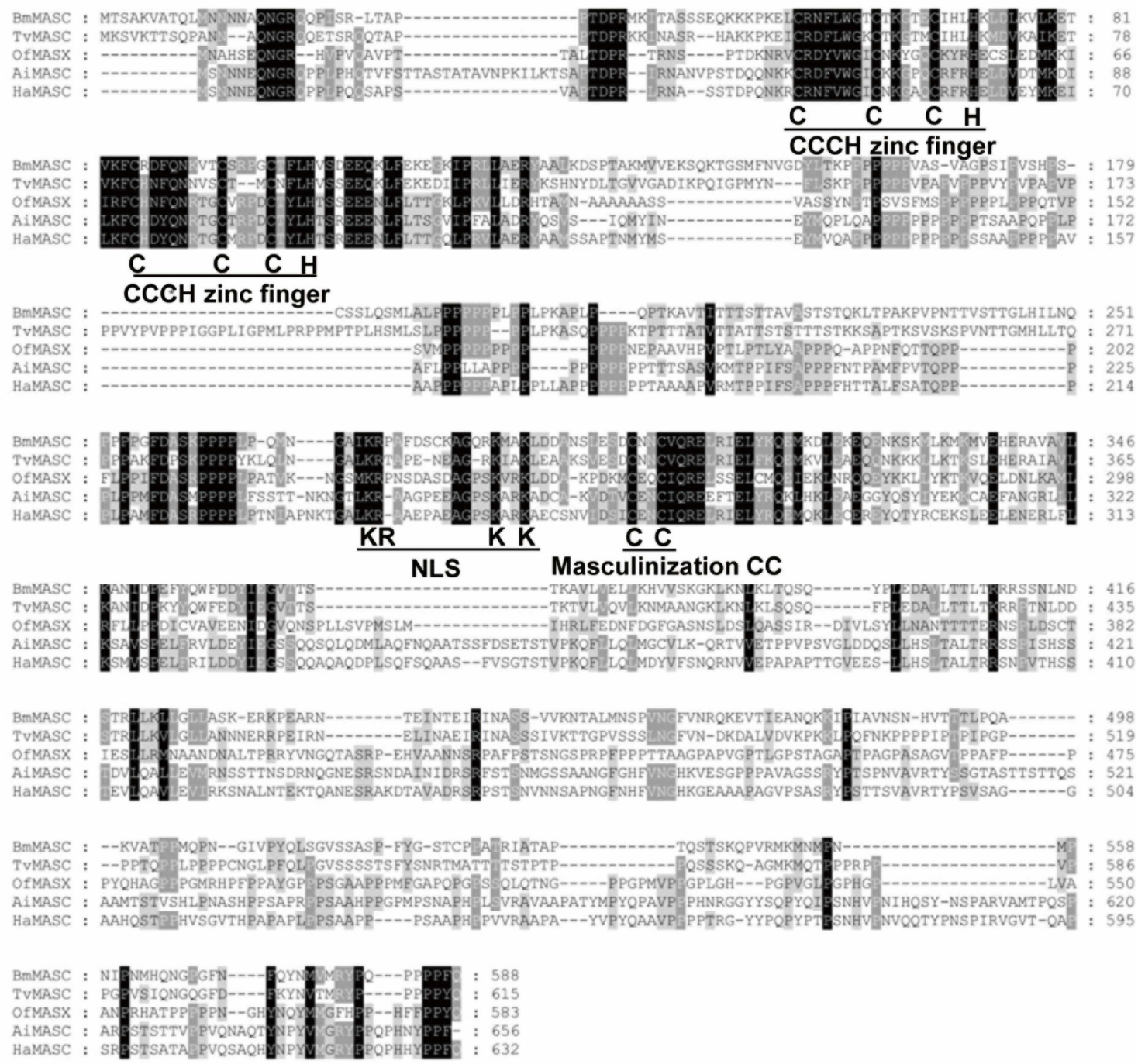

Figure 2. Amino acid alignment of HaMasc with four lepidopteran Masc proteins. Amino acids missed in any of the five Masc proteins are depicted by dashes. Amino acids conserved among all five Masc proteins are shaded in black, whereas those conserved among two to four Masc proteins are shaded in gray. The conserved tandem CCCH-type zinc fingers, nuclear localization signal (NLS), and masculinization CC are underlined. BmMasc = Bombyx mori Masc; TvMasc $=$ Trilocha varians Masc; OfMasc = Ostrinia fumacalis Masc; AiMasc $=$ Agrotis ipsilon Masc; HaMasc $=$ Helicoverpa armigera Masc. 


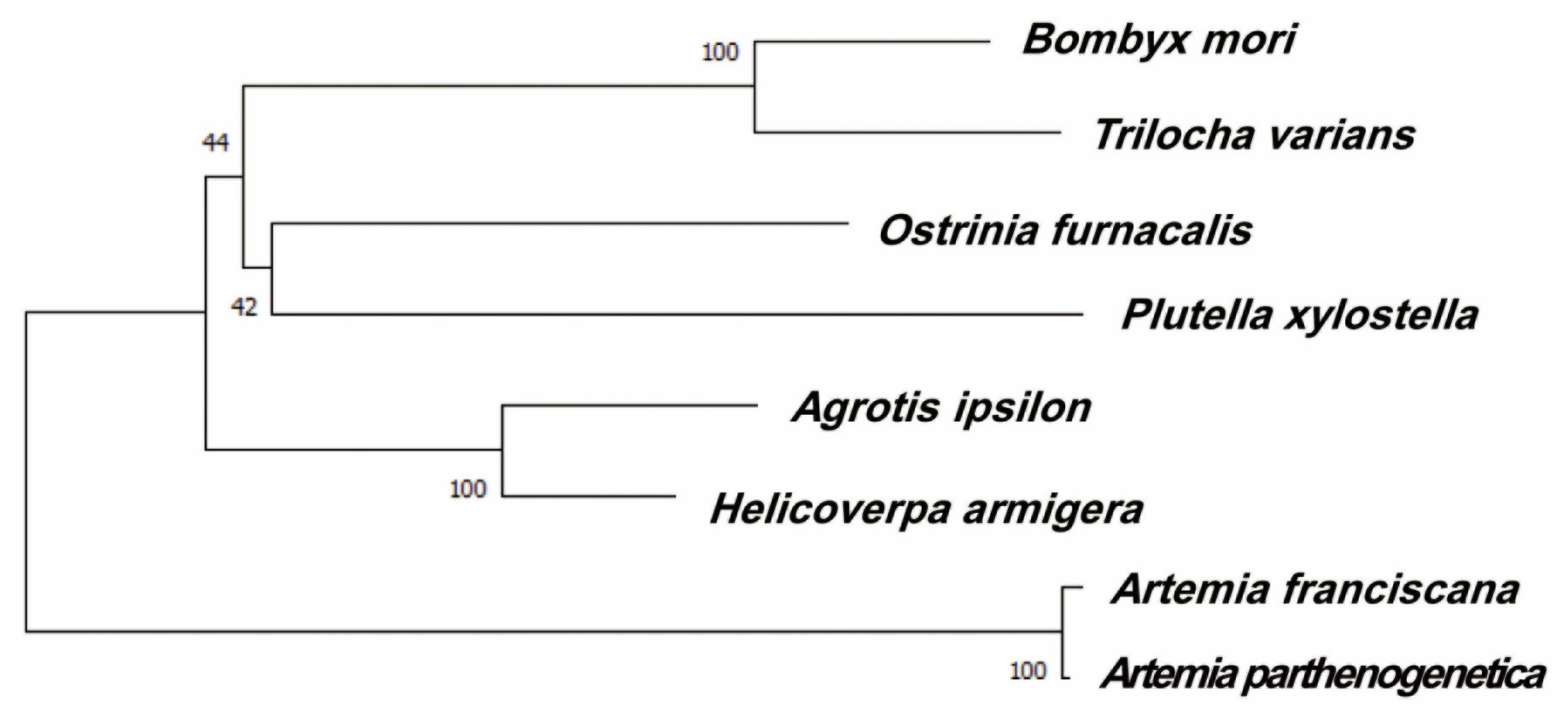

0.20

Figure 3. Phylogenetic relationship among known lepidopteran Masc proteins. The neighbor-joining tree of lepidopteran Masc proteins with two brine shrimp (Artemia species) Masc proteins as the outgroup was drawn with branch length proportional to the inferred amino acid changes. The scale rule for amino acid changes is shown at the bottom. The bootstrap values are shown at the base of each internal branch.

\subsection{Chromosomal Assignment of HaMasc to Z Chromosome}

Genomic PCR gel analysis showed that the band intensity of HaMasc amplified from male (AA $+Z Z=2$ copies of each autosome +2 copies of $Z$ chromosome) pupa was roughly two times of that from female $(\mathrm{AA}+\mathrm{ZW}=2$ copies of each autosome +1 copy of $Z$ chromosome/ 1 copy of $W$ chromosome) pupa, whereas the band intensity of the autosomal gene EF-1 $\alpha$ was equal between the male and female pupa (Figure $4 \mathrm{~A}$ ). Further genomic qPCR analysis revealed that the male copy/female copy ratio was 0.0023 for the W chromosome gene GUW1 [35], 1.00 for the autosomal gene EF- $1 \alpha, 0.98$ for the autosomal gene $\beta$-actin, and 2.32 for HaMasc (Figure 4B). These data confirm that the HaMasc gene is located on $\mathrm{Z}$ chromosome.

\subsection{Sex-, Stage- and Tissue-Specific Expression of HaMasc}

We analyzed the expression of HaMasc at different developmental stages of both sexes (undistinguishable before the fourth instar larvae (L4)) (Figure 5A,B) and in different body parts of newly-emerged male and female adults (Figure 5C) by RT-qPCR analyses of the common region of the two HaMasc isoforms using the primer pair qRT-mascF2 and qRT-mascR2 for RT-qPCR (Table S1; Figure 1B). HaMasc displayed the highest expression in $12 \mathrm{~h}$ eggs, followed by $24 \mathrm{~h}$ eggs, male pupa, male L5, L3-L4, female L5, female pupa, and L1-L2 (Figure 5A). At stages when test insects were sexed by the presence of the W chromosome-specific GUW marker (12 and 24 h eggs) (Deng et al.2020), the presence of testes (L4-L5) or the relative distance between the reproduction and excretion holes (pupa) [36], HaMasc expression was 94.11- (12 h eggs), 43.63- (24 h eggs), 2.94- (L4), 9.4- (L5), and 5.61-fold (pupa) greater in males than that in females (Figure 5A,B), respectively. The difference in HaMasc expression between male and female eggs and pupa was significant but the difference was not significant among L1, L2, L3, L4, female L5, and female pupa (Figure 5A,B). 
A

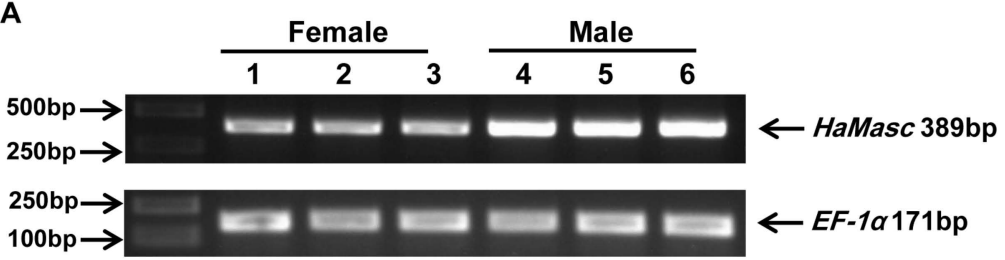

B

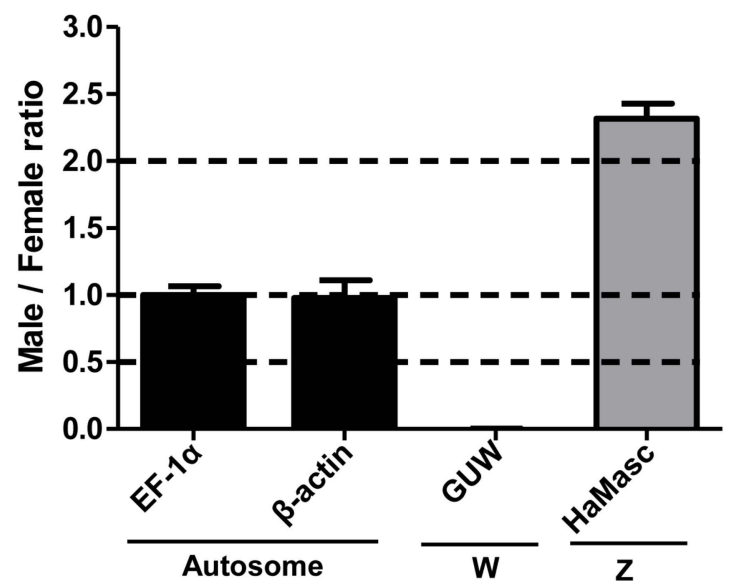

Figure 4. Chromosomal affiliation of HaMasc. (A) Genomic PCR gel analysis of HaMasc and EF-1 . Genomic DNAs extracted from three female pupa (numbered 1, 2,3) and three male pupa $(4,5,6)$ were used as the template to PCR-amplify HaMasc and EF-1 $\alpha$, respectively. A representative gel image of each gene is presented in (A). (B) Genomic qPCR analysis of HaMasc, W-linked GUW1, and autosomal genes $E F-1 \alpha$ and $\beta$-actin. The templates (three male DNA samples and three female DNA samples) used for qPCR are the same as for PCR gel analysis.

Newly emerged male adults had a roughly similar level of HaMasc expression with L3, L4, female L5, and female pupa, whereas female adults exhibited a lower level of HaMasc expression than any other developmental stages (compare Figure 5C vs. Figure 5A). Adult head tissue had a significantly higher level of HaMasc expression than the other four adult tissues examined, including thorax, abdomen, leg, and wing tissues (Figure 5C). In all five body parts, HaMasc expression was numerically (M/F ratio ranged from 1.13 to 1.99) higher in males than in females.

To address which of the two HaMasc isoforms plays a more important role in the $H$. armigera sex-determination pathway, we designed two pairs of isoform-specific primers (see qRT-masc1F/qRT-masc1/2R and qRT-masc2F/qRT-masc1/2R in Table S1 and Figure 1B) to RT-qPCR-analyze the expressions of the two isoforms of HaMasc transcripts in 24-h-old eggs (sexed and unsexed) and 3-d-old male pupae, two stages with the highest expression of HaMasc (Figure 5A,B). As shown in Figure 5D, the expression levels of HaMasc isoform 1 (HaMasc1) in 24-h-old unsexed eggs, 24-h-old male eggs, 24-h-old female eggs, and 3-d-old male pupae were 32.17-, 55.17-, 8.32-, and 23.81-fold greater than those of HaMasc isoform 2 (HaMasc2), respectively, suggesting that HaMasc1 is the dominant isoform and plays a more important role than HaMasc2. 


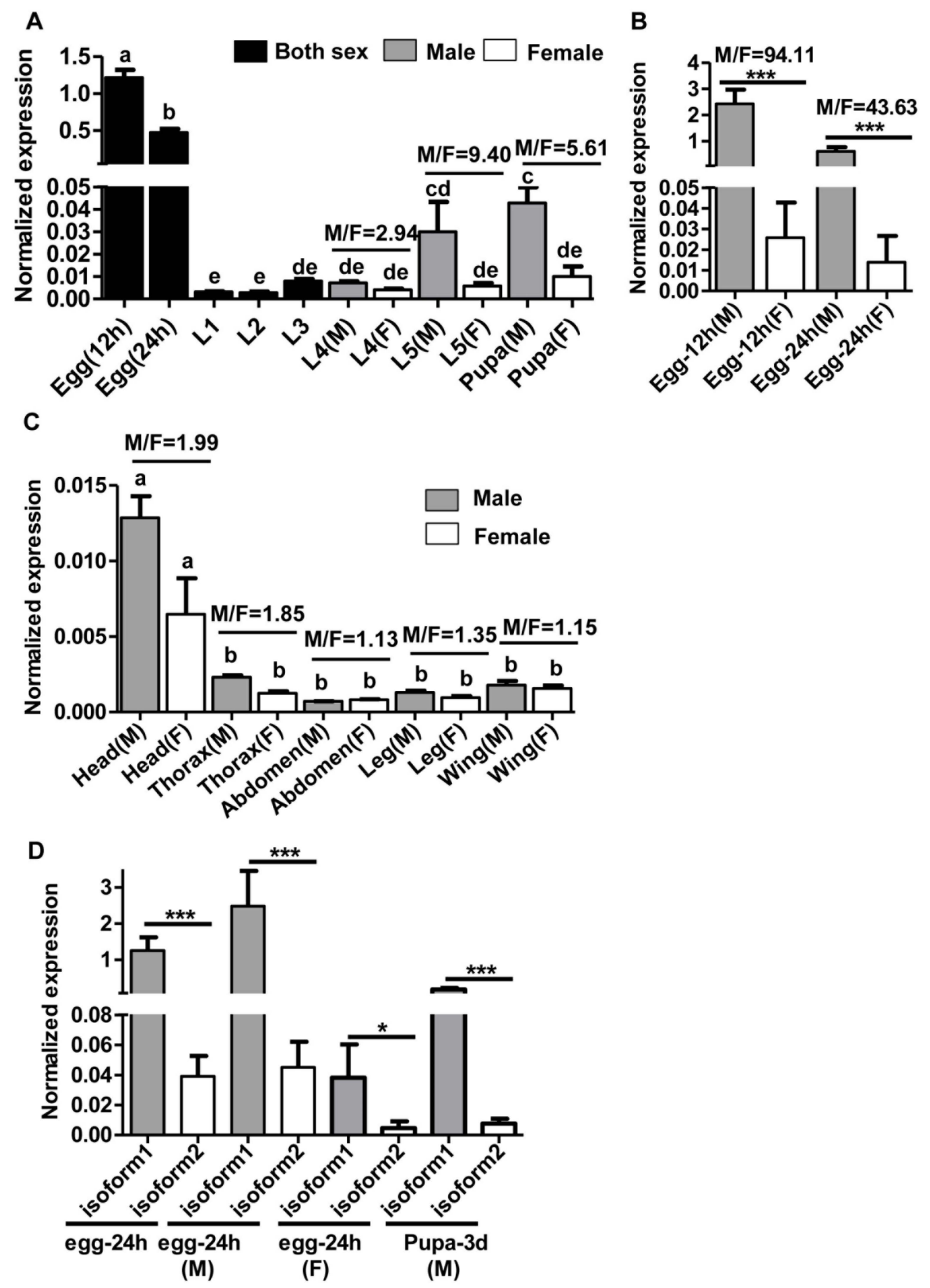

Figure 5. Expression profiles of HaMasc. (A) RT-qPCR analyses of HaMasc in unsexed (eggs to the third instar larvae (L3)) and sexed (L4 (the fourth instar larvae) to pupa) development stages. (B) RT-qPCR analyses of HaMasc in sexed eggs (12 $\mathrm{h}$ and $24 \mathrm{~h}$ ). (C) RT-qPCR analysis of HaMasc in different body parts of newly emerged male (M) and female (F) adults. (D) RT-qPCR analysis of the two HaMasc isoforms (HaMasc1 and HaMasc2) in eggs (24 h, unsexed) and male pupa. Bars in (A-D) are means \pm SE of normalized expression of HaMasc based on at least three biological replicates. Bars with different letters such as a, b, c, d, and e in Figure 5A,C ( $p<0.05$, one-way ANOVA followed by Tukey's HSD test) are significantly different. Bar pairs with one asterisk $(p<0.05$, independent $t$-test) and three asterisks $(p<0.001$, independent $t$-test) in Figure 5B,D are significantly and extremely different, respectively.

\subsection{Suppressing HaMasc Caused Female-Specific Splicing of Hadsx}

Whether a candidate gene functions as an upstream effector gene in the sex-determination pathway of an insect species is dependent on whether knockout/knockdown or overexpression shifts the sex-specific splicing of the terminal double-switch gene $d s x$ from the male-specific to female-specific isoforms or vice versa. The knockout-/knockdowntriggered shift from the male-specific to female-specific $d s x$ splicing isoforms has been used as the essential evidence to verify the masculinizing function of the lepidopteran 
Masc genes examined so far [31-34]. To observe the effects of HaMasc on Hads $x$ splicing, we used RNA interference (RNAi) to knock down HaMasc in the male embryo cell line QB-Ha-E-1 developed from 24-h-old eggs. QB-Ha-E-1 cells were transfected with a mixture of 3 HaMasc siRNAs (Figure 1) or a negative control siRNA (NC siRNA), each at 20 pmol of siRNA per mL of medium. Relative to NC siRNA, HaMasc siRNAs significantly reduced HaMasc transcript abundance (52.82\% reduction) (Figure 6A). In addition, HaMasc siRNAs induced a Hads $x$ splicing shift from male-specific isoforms to female-specific isoforms plus a reduced abundance of male-specific isoforms (Figure 6B).

\section{A. HaMasc: RT-qPCR analysis}

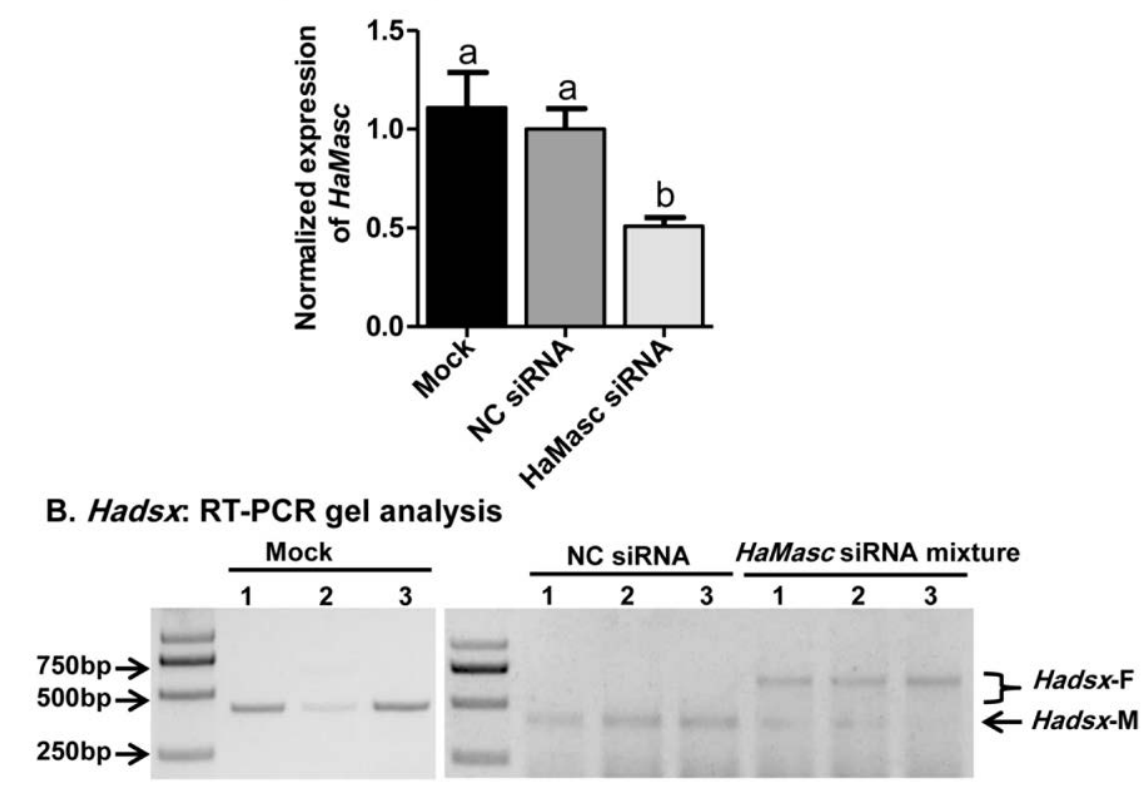

Figure 6. Effects of HaMasc siRNA mixture on the expression of HaMasc and Hads $x$ in the H. armigera male embryo cell line QB-Ha-E-1. (A) RT-qPCR analysis of HaMasc expression, and (B) RT-PCR analysis of sex-specific splicing of Hadsx. Mock was the female and male individual without treatment. Bars in (A) are means \pm SE of normalized expression of HaMasc based on at least three biological replicates of three independent transfections of each siRNA. Bars with different letters $(a, b$ in Figure 6A) are significantly different at $p<0.05$ (one-way ANOVA followed by Tukey's HSD test).

\subsection{Suppressing HaMasc Retarded Male Growth and Testis Development}

To examine the effects of HaMasc on testis development and larval growth, we suppressed HaMasc in H. armigera larvae by a combination of injection and feeding of $\mathrm{ddH}_{2} \mathrm{O}$, NC siRNA, or HaMasc siRNAs. Relative to $\mathrm{ddH}_{2} \mathrm{O}$ and NC siRNA, HaMasc siRNAs not only significantly decreased HaMasc expression in male larvae (44.22\% reduction), female larvae (45.78\% reduction), and 3-d-old male pupae (32.84\% reduction) (Figure 7A), but also induced the appearance of the female-specific splicing isoforms of Hads $x$ in 3-d-old male pupae (Figure 7B). A $t$-test showed that male larvae treated with $\mathrm{ddH}_{2} \mathrm{O}$ or $\mathrm{NC}$ siRNA had a significantly higher expression of HaMasc than the corresponding female larvae (Figure 7A). However, HaMasc siRNA reduced the expression of HaMasc in male larvae to a similar level of HaMasc in female larvae treated with dd $\mathrm{H}_{2} \mathrm{O}$ or NC siRNA (Figure 7A). While HaMasc siRNAs did not affect the gonopore of male pupae (Figure 7C), it significantly reduced the body and testis sizes of male pupae (Figure 7D) as well as the weights of male pupae (13.65\% reduction, Figure 7E) and testis $(55.61 \%$ reduction, Figure 7F). Treatments with HaMasc siRNAs also significantly extended the duration from the third instar larvae to pupa as the percentage of larvae reaching pupal stage on Day 14 post-injection was $10 \%$ for larvae treated with HaMasc siRNAs, but $29 \%$ for larvae with NC siRNA, and $32 \%$ for larvae with $\mathrm{dd}_{2} \mathrm{O}$ in male individuals (Figure $7 \mathrm{G}$ ). In contrast, no differences in HaMasc expression in 3-d-old female pupae (Figure 7A), female pupa 
gonopore (Figure 7B), female pupae body size (Figure 7D), female pupae body weight (Figure 7E), and female pupation rate on Day 14 (Figure 7G) were observed among the three treatment groups. The differences in the pupation rate on Day 14 were not a simple reflection of reduced survival by HaMasc siRNAs (Figure S1).
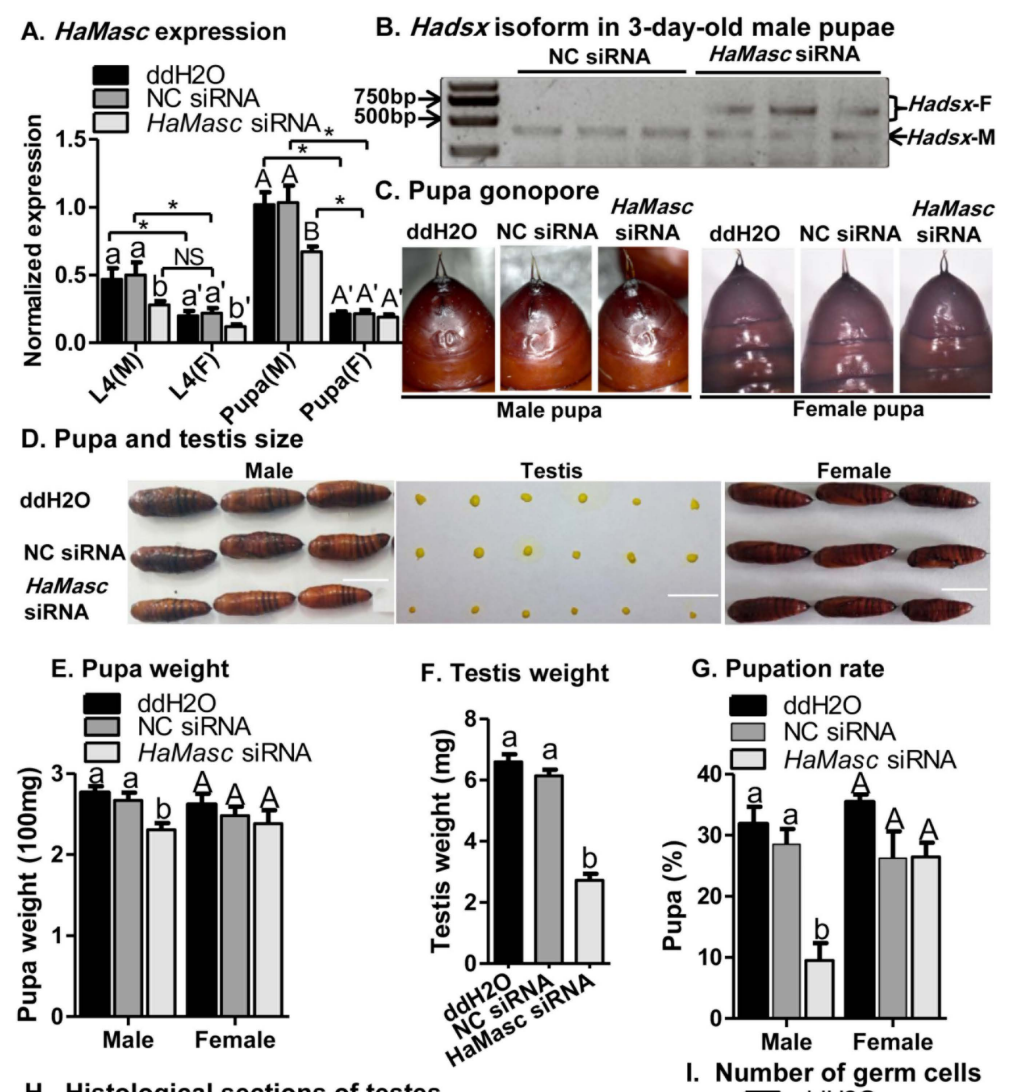

H. Histological sections of testes

I. Number of germ cells

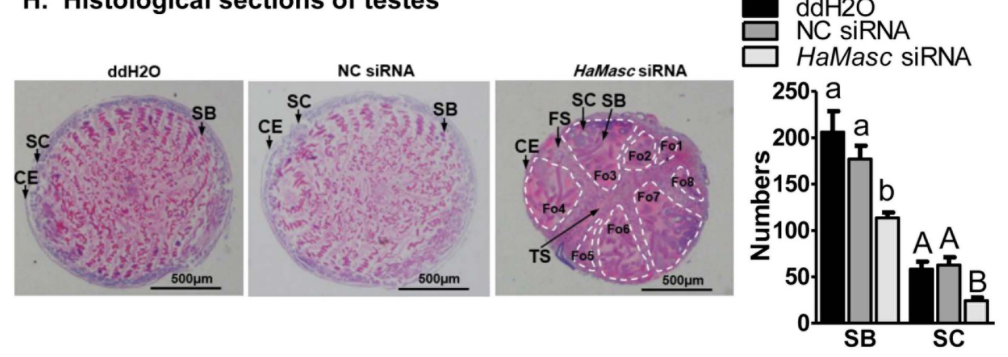

Figure 7. Impacts of HaMasc siRNA mixture on H. armigera larvae. HaMasc expression (A; $\mathrm{M}=$ male, $\mathrm{F}$ = female), splicing of Hads $x$ in 3-day-old male pupae (B), pupa gonopore (C), pupa and testis size (D), pupa weight $(\mathbf{E})$, testis weight $(\mathbf{F})$, pupation rate 2 weeks after delivery of siRNAs $(\mathbf{G})$, testis development and structure and, $(\mathbf{H})$ germ cell number $(\mathbf{I})$. Bars in $(\mathbf{A}, \mathbf{E}-\mathbf{G}, \mathbf{I})$ are means $\pm \mathrm{SE}$ of normalized expression of HaMasc, pupa weight, testis weight, pupation rate, and germ cell number, respectively. Bars with different letters (a, b, A, B, A' in Figure 7A,E-G,I) are significantly different at $p<0.05$ (one-way ANOVA followed by Tukey's HSD test). Photographs of representatives of 3-day-old pupa (D), their gonopore (C), and male testes (D) from each treatment group ( $\mathrm{ddH}_{2} \mathrm{O}$, NC siRNA, HaMasc siRNA mixture) were taken with a camera (D: bar $=1 \mathrm{~cm})$. Hematoxylin and eosin $(\mathrm{HE})$ staining of histological sections of the testis from 3-day-old male pupa $(\mathrm{H}: \mathrm{bar}=500 \mu \mathrm{m})$ shows that the internal fusion process of two bilaterally symmetrical testes into one single testis was completed in $\mathrm{ddH}_{2} \mathrm{O}$ and $\mathrm{NC}$ siRNA pupa but not in HaMasc siRNAs pupa, as manifested by the presence of septa between the two testes (TS in $\mathbf{H}$ ) and between the four follicles within each testis (FS in $\mathbf{H}$ ) in HaMasc siRNAs pupa but not in ddH $_{2} \mathrm{O}$ and NC siRNA pupa. The notable eight follicles (Fo 1-8) in HaMasc siRNAs pupa are surrounded by white dotted lines. FS = follicle septa, TS = testis septa, $\mathrm{CE}=$ coating epithelium, $\mathrm{SC}=$ spermatocytes, $\mathrm{SB}$ $=$ sperm bundle. Bar pairs with one asterisks $(p<0.05$, independent $t$-test). 
Externally, $3 \mathrm{~d}$ after pupation, in all three injection/feeding groups, the process of fusing two bilaterally symmetrical testes into one single testis was completed (Figure 7D). The histological section, however, showed that such was true only for $\mathrm{ddH}_{2} \mathrm{O}$-and-NCsiRNA-treated pupa, but not for HaMasc-siRNAs-treated pupa (Figure 7H). This was evidenced by the presence of septa between the two testes (TS in Figure $7 \mathrm{H}$ ) and between the four follicles within each testis (FS in Figure 7H) in the HaMasc-siRNA-treated pupa, but not in the $\mathrm{ddH}_{2} \mathrm{O}$-and-NC-siRNA-treated pupa. Obvious twisting was observed in $\mathrm{ddH}_{2} \mathrm{O}$ and-NC siRNA-treated pupa, but not in HaMasc-siRNAs-treated pupa. Spermatocytes (SC) were larger and sperm bundles (SB) were longer in HaMasc-siRNAs-treated pupa than in $\mathrm{ddH}_{2} \mathrm{O}$-and-NC-siRNA-treated pupa. There were significantly fewer SC and SB in HaMasc-siRNA-pupa than in $\mathrm{ddH}_{2} \mathrm{O}$-and-NC-siRNA-pupa (Figure 7H,I).

\section{Discussion}

BmMasc, the target gene of the primary signal Fem piRNA in the B. mori sex determination cascade [6,37], is expected to evolve rapidly according to Wilkins's "bottom-up" theory $[7,9]$, and thus, may or may not have a recognizable homolog in $H$. armigera since the two lepidopterans belong to two distant families [38,39]. The data obtained in this study confirm that the H. armigera homolog of BmMasc, HaMasc, does exist in the H. armigera genome and transcriptome (Figure 1), although its amino acid identity (only $25 \%$ ) with BmMasc (Table 1; Figure 2) fails to meet the widely accepted 30\% criterion for homology identification [40]. One reason for this homology assignment is that HaMasc contains all known functional domains of BmMasc including two tandem CCCH-type zinc fingers, one bipartite nuclear localization signal, and one masculinization CC (Figure 2), which are required for masculinizing and/or dosage compensation activity of BmMasc [41-43]. Another is that Mascs from Agrotis ipsilon (AiMasc) [33], Ostrinia fumacalis (OfMasc) [32], and Plutella xylostella (PxMasc) [34] play a similar male-determining role in the three species, even though their amino acid sequence identities with BmMasc are even lower than that of HaMasc with BmMasc, ranging from $19.74 \%$ to $22.48 \%$ (Table 1 ).

Other than low amino acid sequence identity, as described above, the rapid evolution of Masc genes is also evidenced by their variations in gene structure and alternative splicing among and within families. The exon number varies from 10 in B. mori Masc [44] to 11 in A. ipsilon Masc [33], 12 in H. armigera Masc (Figure 1A), and 13 in P. xylostella Masc [34]. A. ipsilon Masc yields one constitutively spliced transcript only [33], whereas Masc from $B$. mori [44], H. armigera (Figure 1), and P. xylostella [34] produce not only one constitutively spliced transcript but also one alternatively spliced transcript. Moreover, the alternatively spliced transcript is generated by the presence of an alternative $3^{\prime}$ splicing site in exon 9 of BmMasc, the retention of intron 1 in HaMasc (Figure 1), and the skipping of exon 5-12 in PxMasc [34], respectively.

Despite the above divergences in gene structure, alternative splicing type, and amino acid sequence, the data from the current study on HaMasc's chromosomal affiliation (Figure 4), expression profiles (Figure 5), and functions (Figures 6 and 7) reveal that HaMasc is functionally homologous to BmMasc and other identified lepidopteran Masc proteins. Similar to BmMassc [6] and PxMasc [34], HaMasc is a Z chromosome-linked protein-coding gene, since its genomic copy number was two times higher in males than in females (Figure 4). The highest expression of HaMasc in the embryonic stage ( $12 \mathrm{~h}$ and $24 \mathrm{~h}$ after oviposition) (Figure 5) not only corresponds to the developmental expression profiles of BmMasc [6] and PxMasc [34] but also agrees with the notion that sex is determined developmentally upon embryogenesis [1-3]. Sexually, HaMasc expression, similar to BmMasc expression [6], was higher in males than in females (Figure 5), indicating that an unidentified primary signal, resembling Fem piRNA in female silkworms, diminishes HaMasc expression in female cotton bollworms. Functionally, HaMasc is required for the regulated male-specific splicing of Hadsx because RNAi suppression of HaMasc induced a Hads $x$ splicing shift from male-specific isoforms only to female-specific isoforms plus a reduced abundance of male-specific isoforms in the H. armigera male embryo cell line 
QB-Ha-E-1 (Figure 6) and male pupae (Figure 7B). Furthermore, the knockdown of HaMasc starting from the third instar larvae resulted in a series of male-specific phenotypic defects including smaller male pupa and testes, fewer but larger/longer spermatocytes and sperm bundles, delayed pupation and internal fusion of the testes and follicles (Figure 7). The delay of testes / follicle fusion and spermatogenesis, the major remaining steps of male gonad development post-HaMasc depletion from the third instar larvae plus the observed HaMacsregulated shift of Hadsx splicing in vitro (Figure 6) and in vivo (Figure 7B) demonstrate that HaMasc functions as a male-determinant targeted by the unidentified female-specific primary signal in the $H$. armigera sex-determination cascade.

While several lepidopteran Masc proteins have been functionally studied [32-34], this study reports for the first time that Masc knockdown suppresses male growth and body size/weight (Figure 7D,E,G). This is not a surprise since at least two upstream sexdetermination pathways genes have been found to promote growth, development, and body size of the sex in which they are expressed [45-47]. In male B. mori, the loss of BmImp, the autoregulatory key gene immediately downstream of BmMasc [25], suppresses larval growth and reduces body size [46]. Additionally, in male B. mori, lack of the CCCH-type zinc finger gene $B m z n f-2$, a recently discovered redundant masculinizer of the CCCH-type zinc finger gene BmMasc [48], results in developmental delay and smaller body sizes of male larvae [47]. Given the functional similarity of Masc with Bmznf-2, its regulatory relationship with BmImp, and involvement in dosage compensation [41-43], HaMasc may regulate male growth and body size/weight by itself, indirectly via its immediate downstream gene, i.e., the $H$. armigera homolog of BmImp, or by dosage compensation. Additional experiments are needed to resolve the three possibilities.

The female-specific primary signal in $H$. armigera is most likely a non-coding RNA belonging to piRNA, micro-RNA, or long non-coding RNAs. This is because the femalespecific W chromosome in Lepidoptera is packed with transposons that can be transcribed into non-coding RNAs [6,49-51]. Our recent characterization of the first W-specific proteincoding gene GUW1 from $H$. armigera [35] suggests that the W-specific GUW1 may function as the primary signal to minimize HaMasc expression in female cotton bollworms. Further experiments are required to examine these two possibilities.

\section{Materials and Methods}

\subsection{Insects}

The H. armigera strain used in this study was collected from tobacco fields in Xuchang City (Henan Province, China) and was reared under laboratory conditions $\left(28{ }^{\circ} \mathrm{C}\right.$ with a photoperiod of 14L:10D, and $75 \pm 5 \%$ R.H.) [52]. Larvae were reared individually in disposable plastic cups on a casein-based artificial diet as previously described [53]. Cotton wicks soaked with a $10 \%$ honey solution were provided for adult moths to supplement adult feeding.

\subsection{DNA and RNA Isolation and Reverse Transcription}

Three male and three female genomic DNA samples of $H$. armigera were extracted from $100 \mathrm{mg}$ tissues of three frozen male and female pupae, respectively, using the same procedure as described previously by Li et al. [54]. The purified DNA samples were dissolved in double-distilled water $\left(\mathrm{ddH}_{2} \mathrm{O}\right)$, measured using the NanoDrop 1000 (Thermo Scientific, Logan, UT, USA), and stored at $-20^{\circ} \mathrm{C}$ for subsequent genomic PCR-gel analysis and genomic quantitative PCR (qPCR) analysis of HaMasc.

RNA samples were extracted from a variety of insect tissues throughout its life cycle, including eggs, larvae of the first to the last instars (separation of male and female larvae after third instars), male pupa, female pupa, and head, thorax, abdomen, leg, and wings of newly emerged male and female adults of $H$. armigera. Total RNA was extracted with a Trizol reagent (Invitrogen, Carlsbad, CA, USA) following the manufacturer's instructions. The RNA concentration was measured by the NanoDrop 1000 (Thermo Scientific). Before reverse transcription, the RNA was treated with DNase I (Promega, Madison, WI, USA) 
with an RNase inhibitor (Thermo Scientific) following the manufacturer's instructions to avoid genomic DNA (gDNA) contamination. Two $\mu \mathrm{g}$ RNA were reverse transcribed into the first strand of cDNA using the Quant Reverse transcriptase kit (Tiangen Biotech, Beijing, China). The primer used was a mixture of the 6-mer random primer and the oligo(dT) primer. The cDNA products were diluted using $\mathrm{ddH}_{2} \mathrm{O}$ and stored at $-80{ }^{\circ} \mathrm{C}$ for subsequent RT-PCR cloning and/or RT-qPCR analysis amplification of $H$. armigera Masc (HaMasc).

\subsection{Cloning of H. armigera Masc cDNA Sequence}

A contig containing the partial cDNA sequence (Transcriptome annotated number: asmbl_65189) of HaMasc was retrieved by TBLASTN search of an H. armigera larval transcriptome dataset [30] using BmMasc amino acid sequences (NP_001296506.1) as a query sequence. This partial sequence was further verified by RT-PCR cloning using the aforementioned egg cDNA as the template and the primers Harm-mascF2 and Harm-mascR2 (Table S1; Figure 1) designed based on the retrieved contig asmbl_65189. The PCR conditions were $95{ }^{\circ} \mathrm{C}$ for $5 \mathrm{~min}$; 40 cycles of $10 \mathrm{~s}$ at $98^{\circ} \mathrm{C}$, $15 \mathrm{~s}$ at $60^{\circ} \mathrm{C}$, and $3 \mathrm{~min}$ at $68^{\circ} \mathrm{C}$; and the final extension at $68^{\circ} \mathrm{C}$ for $5 \mathrm{~min}$. The resultant PCR product was cloned into a pGEM-T Easy vector (Promega, Madison, WI, USA) and sequenced by Sangon Biotech (Shanghai, China). To obtain the full-length cDNA sequence of HaMasc, we performed $3^{\prime}$ and $5^{\prime}$ RACE reactions using egg RNA as the template and the SMARTer RACE cDNA Amplification Kit (Clontech, Mountain View, CA, USA) following the manufacturer's instructions. The general and HaMasc-specific primers used in the $3^{\prime}$ and $5^{\prime}$ RACE are listed in Table S1. The two full-length isoforms of HaMasc transcripts have been deposited in the GenBank database (accession number: MH844486 and MH844487).

\subsection{Analysis of HaMasc Sequence}

The open reading frames (ORFs) of the two full-length cDNA sequences of HaMasc were predicted using the ORF search tool within the Clone Manager 8 Software (Scientific and Educational Software, Durham, USA). The similarity of multiple Masc protein sequences was analyzed using DNAMAN (Version 8.0, Lyn-non Biosoft, Canada). The exons and introns of HaMasc were identified by aligning its cDNA sequences to its HaMasc's genome sequence (Li et al., unpublished genome data) and the gene structure was generated using the Gene Structure Display Server 2.0 [55]. The conserved domains among known Masc proteins were identified using the multiple sequence alignment software Mega X [56], NCBI sequence analysis tools CDD (NCBI's conserved domain database) [57], and the GeneDoc multiple sequence alignment tool [58].

Masc amino acid sequences of Agrotis ipsilon (Sequence reference [33], Artemia franciscana (accession number: ARB66312.1), Artemia parthenogenetica (accession number: ARB66313.1), B. mori (accession number: NP_001296506.1), Trilocha varians (accession number: BAS02075.1), and Ostrinia fumacalis (accession number: BAS02074.1) were obtained from the NCBI protein database. The Masc protein sequences were aligned using the ClustalW tool in MEGA [56] and the phylogenic tree was constructed using the neighborjoining method.

\subsection{Genomic PCR and qPCR Analysis of HaMasc}

The male and female pupal DNA samples obtained above were used as the templates for qPCR analysis of HaMasc, two autosomal genes Elongation factor 1 alpha (EF-1 $\alpha$; GeneBank accession number: FJ768770.1), beta-Actin ( $\beta$-actin; GeneBank accession number: EU527017.1), and one W chromosome gene GUW1 [35]. The qPCR reactions for each of the four genes contained $1 \mu \mathrm{L}$ of male or female DNA (100 ng), $10 \mu \mathrm{L} 2 \times$ SuperReal PreMix Plus (SYBR Green, Tiangen), $0.4 \mu \mathrm{L}$ of ROX Reference Dye, $1 \mu \mathrm{L}$ gene-specific forward primer, and $1 \mu \mathrm{L}$ gene-specific reverse primer (see Table S1 and Figure 1), and 7.6 $\mu \mathrm{L}$ RNase-free water. The qPCR cycling conditions were the same as previously described for RT-PCR cloning of the HaMasc partial sequence. 
The two DNA samples were also used as the templates for PCR-gel analysis of HaMasc with the primer pair Hamasc-1220F and Hamasc-1352R (Table S1) and EF-1 $\alpha$ with the primer pair EF-F and EF-R (Table S1). The genomic PCR reactions for each of the two genes included $1 \mu \mathrm{L}$ (100 ng) of male or female DNA, $1 \mu \mathrm{L}$ PrimeSTAR GXL DNA polymerase, $10 \mu \mathrm{L} 5 \times$ PCR buffer, $2.5 \mu \mathrm{L}$ gene-specific forward primer, $2.5 \mu \mathrm{L}$ gene-specific reverse primer, and $33 \mu \mathrm{L}$ RNase-free water. The PCR cycling conditions were the same as what was used for the RT-PCR cloning of the HaMasc partial sequence. The resultant PCR products were fractioned on $1.2 \%$ agarose gel and visualized by ethidium bromide fluorescent staining.

\subsection{RT-qPCR Analyses of HaMasc Expression}

The cDNA samples prepared above were used as the templates for the RT-qPCR analysis of HaMasc expression in eggs, larvae of the first to the last instars, male pupa, female pupa, and different body parts of newly emerged male and female adults of $H$. armigera. The RT-qPCR reactions contained $1 \mu \mathrm{L}$ of each cDNA sample, $10 \mu \mathrm{L} 2 \times$ SuperReal PreMix Plus (SYBR Green, Tiangen), $0.4 \mu \mathrm{L}$ of ROX Reference Dye, $1 \mu \mathrm{L}$ gene-specific forward primer, $1 \mu \mathrm{L}$ gene-specific reverse primer, and 7.6 $\mu \mathrm{L}$ RNase-free water. The RT-qPCR running conditions were $95^{\circ} \mathrm{C}$ for $5 \mathrm{~min} ; 40$ cycles of $10 \mathrm{~s}$ at $98{ }^{\circ} \mathrm{C}, 15 \mathrm{~s}$ at $60{ }^{\circ} \mathrm{C}$, and $3 \mathrm{~min}$ at $68^{\circ} \mathrm{C}$; and the final extension at $68^{\circ} \mathrm{C}$ for $5 \mathrm{~min}$ on an ABI 7500 real-time PCR instrument (Applied Biosystems, Foster City, CA). The gene-specific forward and reverse primers for RT-qPCR analyses of HaMasc and the two reference genes EF- $1 \alpha$ and $\beta$-actin are listed in Table S1. Each developmental stage or body part had three independent biological replicates; RT-qPCR analysis of each biological replicate was repeated three times. The normalized expressions of HaMasc in each developmental stage or body part were calculated using the $2^{-\Delta \Delta C t}$ method [59].

\subsection{RNAi Knockdown of HaMasc in H. armigera Embryo Cell Line and Larvae 4.7.1. RNAi Knockdown of HaMasc in H. armigera Cell Line}

Three 3'end 2'-O-Methyl-modified and 5'end 5'-Cholesterol small interfering RNAs (siRNA) targeting at different regions of HaMasc (see Figure 1) and one negative control siRNA (NC siRNA) were designed and synthesized by Ribobio Biotech (Guangzhou, China) to knock down the endogenous HaMasc in $H$. armigera larvae and embryo cell line QB-Ha-E-1 [60], respectively. QB-Ha-E-1 cells were routinely cultured at $28{ }^{\circ} \mathrm{C}$ with Grace's Insect Medium (Gibco/Life Technologies, New York, NY, USA) supplemented with a 10\% fetal bovine serum (Gibco/Life Technologies, New York, NY, USA), 50 U/mL penicillin, and $50 \mu \mathrm{g} / \mathrm{mL}$ streptomycin (HyClone, Thermo Scientific, Logan, UT, USA). QB-Ha-E-1 cells seeded onto 12-well plates grew to 70\% confluence, we transfected each well of cells with $1 \mu \mathrm{L}$ of a 1:1:1 mixture of the three HaMasc siRNAs (total 3 siRNAs 20 pmol) or equal amount and volume of NC siRNA using the transfection agent Lipofectamine 3000 (Thermo Scientific, Logan, UT, USA) according to the product manual. Briefly, we added $2 \mu \mathrm{L}$ of Lipofectamine 3000 and $1 \mu \mathrm{L}$ of HaMasc siRNA mixture or NC siRNA into a $1.5 \mathrm{~mL}$ microcentrifuge containing $50 \mu \mathrm{L}$ of serum-free Grace's medium, mixed it well, incubated it for $15 \mathrm{~min}$ at room temperature, and transferred the whole mixture to one well of cells. The medium in each well was gently replaced with fresh completed Grace's medium $12 \mathrm{~h}$ post-transfection. After another $72 \mathrm{~h}$, the cells in each well were harvested, flash-frozen in liquid nitrogen, and stored at $-80^{\circ} \mathrm{C}$ for subsequent RNA extraction, and RT-PCR and/or RT-qPCR analyses of HaMasc and H. armigera dsx (Hadsx). RT-PCR and RT-qPCR analyses of HaMasc were performed as described above, while RT-PCR gel analysis of Hadsx transcript isoforms was conducted under the conditions described later (see below).

\subsubsection{RNAi Knockdown of HaMasc in H. armigera Larvae}

Third instar larvae within $6 \mathrm{~h}$ of molting were individually microinjected with a microinjector consisting of a $5 \mu \mathrm{L}$ syringe connected to a capillary glass needle (Figure S2) from their dorsal intersegmental membrane between abdominal segment 2 and 3 with 
$0.1 \mu \mathrm{L} \mathrm{ddH}_{2} \mathrm{O}$, NC siRNA (20 pmol/ $\left.\mu \mathrm{L}\right)$, or a 1:1:1 mixture of the three HaMasc siRNAs (total 3 siRNAs concentration $20 \mathrm{pmol} / \mu \mathrm{L})$ [61]. Three replicates of 30 larvae each $(\mathrm{N}=90)$ were injected for each control or siRNA treatment. The injected larvae were then reared in 1 OZ plastic cups (1 larva/cup) containing the corresponding $\mathrm{KOH}$-free diets supplemented with $20 \mathrm{pmol} / \mathrm{g}$ diets of $\mathrm{ddH}_{2} \mathrm{O}, \mathrm{NC}$ siRNA, or a 1:1:1 mixture of the 3 HaMasc siRNAs (see their target regions in Figure 1B) [62]. Three male and three female fourth instar larvae per replicate were randomly flash-frozen with liquid nitrogen and stored at $-80^{\circ} \mathrm{C}$ for subsequent RNA extraction, RT-PCR, and RT-qPCR analyses of HaMasc $72 \mathrm{~h}$ postmicroinjection.

The remaining 24 larvae of each replicate were then transferred to cups containing the corresponding freshly made $\mathrm{ddH}_{2} \mathrm{O}$ diets, NC siRNA diets, or HaMasc siRNAs diets. The old diets in each cup were replaced with the corresponding fresh ones every $72 \mathrm{~h}[61,62]$. Larvae were reared on the respective diets until pupation or up to two weeks. Pupae were individually sexed, photographed, weighed, flashed-frozen in liquid nitrogen, and stored at $-80^{\circ} \mathrm{C}$ for the subsequent analysis of HaMasc expression and Hads $x$ splicing as well as the dissection and hematoxylin-eosin staining of pupal testes after development at $28^{\circ} \mathrm{C}$ for $3 \mathrm{~d}$. The survival and pupation rates of male and female individuals two weeks post-injection were recorded.

\subsection{Hematoxylin-Eosin (HE) Staining of Pupal Testes}

Pupal samples from each control or siRNA treatment were obtained from the $-80{ }^{\circ} \mathrm{C}$ freezer, thawed at room temperature, and individually dissected to get testes. Testes were individually weighed, fixed overnight in Bouin's fluid [63], photographed, paraffinembedded, sectioned into $10 \mu \mathrm{m}$-thick slices with a Leica RM2235, and stained using a mixture of hematoxylin and eosin solution (Sangon Biotech, E607318). The stained testis sections were observed and photographed under a microscope (CX53, Olympus, Japan).

\subsection{RT-PCR Gel Analysis of Female and Male-Specific Isoform of Hadsx Transcript}

After HaMasc was knocked down in 3-d-old male pupae or the male cell line QB-HaE-1, sex-specific splicing isoforms of H. armigera doublesex (Hadsx) transcripts were detected by RT-PCR. The RNA extraction, reverse transcription, and PCR reaction procedures and experimental conditions were the same as described above for HaMasc. The primers used for Hads $x$ RT-PCR are listed in Table S1 (Ha-DX-exo2F and Ha-DX-exo6R, which produced a $419 \mathrm{bp}$ amplicon in control males but four amplicons of 668, 683, 797, and $812 \mathrm{bp}$ in control females. EF-1 $\alpha$ (primer list in Table S1) was used as the endogenous control.

\section{Data Analysis}

One-way analysis of variance (ANOVA) followed by Tukey's HSD tests was performed to determine differences in HaMasc expression among different tissues, developmental stages, and larvae with different siRNA injection/feeding treatments, as well as in pupation rate and pupa and testis weights among larvae with different siRNA injection/feeding treatments. We conducted independent $t$-tests to compare the expressional differences of HaMasc between cells transfected with an NC siRNA or a HaMasc siRNA mixture. All statistical analyses were performed in SPSS version 19.0 (SPSS Inc., Chicago, IL, USA).

Supplementary Materials: The following are available online at https:/ / www.mdpi.com/article/10 $.3390 /$ ijms22168650/s1.

Author Contributions: X.L. and Z.D. conceived and designed the experiments. Z.D., Y.Z. and Y.L. performed the experiments. X.L., K.H., X.C., Y.Z., X.N. and Z.D. analyzed the data. X.L., Y.Z., X.C., Z.D., J.H., X.N. and M.Z. wrote the manuscript. All authors have read and agreed to the published version of the manuscript.

Funding: This research was supported by the National Science Foundation of China (NSFC)Henan Joint major grant (No. U2004206), State Key Laboratory of Cotton Biology Open Fund (No. CB2020A06), Key Scientific Research Projects of Colleges and Universities in Henan Province 
(No. 21A210027), and the USDA National Institute of Food and Agriculture (Hatch Project No. ARZT-1370680-R31-172, ARZT-1360890-H31-164, and multi-state grant ARZT-1370400-R31-168).

Institutional Review Board Statement: Not applicable.

Informed Consent Statement: Not applicable.

Data Availability Statement: All data supporting results are included in the Supplementary Files.

Conflicts of Interest: The authors declare no competing financial interest.

\section{References}

1. Salz, H.K. Sex determination in insects: A binary decision based on alternative splicing. Curr. Opin. Genet. Dev. 2011, 21, 395-400. [CrossRef]

2. Bopp, D.; Saccone, G.; Beye, M. Sex determination in insects: Variations on a common theme. Sex. Dev. 2014, 8, 20-28. [CrossRef] [PubMed]

3. Biedler, J.K.; Tu, Z. Sex Determination in Mosquitoes. Adv. Insect Physiol. 2016, 51, 37-66.

4. Nagaraju, J.; Gopinath, G.; Sharma, V.; Shukla, J.N. Lepidopteran sex determination: A cascade of surprises. Sex. Dev. 2014, 8, 104-112. [CrossRef] [PubMed]

5. Salz, H.K.; Erickson, J.W. Sex determination in Drosophila the view from the top. Fly 2010, 4, 60-70. [CrossRef]

6. Kiuchi, T.; Koga, H.; Kawamoto, M.; Shoji, K.; Sakai, H.; Arai, Y.; Ishihara, G.; Kawaoka, S.; Sugano, S.; Shimada, T.; et al. A single female-specific piRNA is the primary determiner of sex in the silkworm. Nature 2014, 509, 633-636. [CrossRef] [PubMed]

7. Sawanth, S.K.; Gopinath, G.; Sambrani, N.; Arunkumar, K.P. The autoregulatory loop: A common mechanism of regulation of key sex determining genes in insects. J. Biosci. 2016, 41, 283-294. [CrossRef]

8. Aryan, A.; Anderson, M.A.E.; Biedler, J.K.; Qi, Y.M.; Overcash, J.M.; Naumenko, A.N.; Sharakhova, M.V.; Mao, C.H.; Adelman, Z.N.; Tu, Z.J. Nix alone is sufficient to convert female Aedes aegypti into fertile males and myo-sex is needed for male flight. Proc. Natl. Acad. Sci. USA 2020, 117, 17702-17709. [CrossRef] [PubMed]

9. Wilkins, A.S. Moving up the hierarchy: A hypothesis on the evolution of a genetic sex determination pathway. BioEssays News Rev. Mol. Cell. Dev. Biol. 1995, 17, 71-77. [CrossRef]

10. Hasselmann, M.; Gempe, T.; Schiott, M.; Nunes-Silva, C.G.; Otte, M.; Beye, M. Evidence for the evolutionary nascence of a novel sex determination pathway in honeybees. Nature 2008, 454, 519-522. [CrossRef] [PubMed]

11. Bachtrog, D.; Mank, J.E.; Peichel, C.L.; Kirkpatrick, M.; Otto, S.P.; Ashman, T.L.; Hahn, M.W.; Kitano, J.; Mayrose, I.; Ming, R.; et al. Sex determination: Why so many ways of doing it? PLoS Biol. 2014, 12, e1001899. [CrossRef]

12. Baker, R.H.; Sakai, R.K. Triploids and male determination in the mosquito, Anopheles culicifacies. J. Hered 1979, 70, 345-346. [CrossRef]

13. Willhoeft, U.; Franz, G. Identification of the sex-determining region of the Ceratitis capitata $\mathrm{Y}$ chromosome by deletion mapping. Genetics 1996, 144, 737-745. [CrossRef]

14. Shukla, J.N.; Palli, S.R. Production of all female progeny: Evidence for the presence of the male sex determination factor on the $Y$ chromosome. J. Exp. Biol. 2014, 217, 1653-1655. [CrossRef]

15. Charlesworth, D.; Mank, J.E. The birds and the bees and the flowers and the trees: Lessons from genetic mapping of sex determination in plants and animals. Genetics 2010, 186, 9-31. [CrossRef] [PubMed]

16. Hall, A.B.; Basu, S.; Jiang, X.F.; Qi, Y.M.; Timoshevskiy, V.A.; Biedler, J.K.; Sharakhova, M.V.; Elahi, R.; Anderson, M.A.E.; Chen, X.G.; et al. A male-determining factor in the mosquito Anopheles gambiae. Science 2015, 348, 1268-1270. [CrossRef] [PubMed]

17. Hall, A.B.; Papathanos, P.A.; Sharma, A.; Cheng, C.; Akbari, O.S.; Assour, L.; Bergman, N.H.; Cagnetti, A.; Crisanti, A.; Dottorini, T.; et al. Radical remodeling of the Y chromosome in a recent radiation of malaria mosquitoes. Proc. Natl. Acad. Sci. USA 2016, 113, E2114-E2123. [CrossRef]

18. Krzywinska, E.; Dennison, N.J.; Lycett, G.J.; Krzywinski, J. A maleness gene in the malaria mosquito Anopheles gambiae. Science 2016, 353, 67-69. [CrossRef] [PubMed]

19. Criscione, F.; Qi, Y.M.; Tu, Z.J. GUY1 confers complete female lethality and is a strong candidate for a male-determining factor in Anopheles stephensi. Elife 2016, 5, e19281. [CrossRef]

20. Sharma, A.; Heinze, S.D.; Wu, Y.L.; Kohlbrenner, T.; Morilla, I.; Brunner, C.; Wimmer, E.A.; van de Zande, L.; Robinson, M.D.; Beukeboom, L.W.; et al. Male sex in houseflies is determined by Mdmd, a paralog of the generic splice factor gene CWC22. Science 2017, 356, 642-645. [CrossRef] [PubMed]

21. Meccariello, A.; Salvemini, M.; Primo, P.; Hall, B.; Koskiniot, P.; Dalikova, M.; Gravina, A.; Gucciar, M.A.; Forlenza, F.; Gregoriou, M.E.; et al. Maleness-on-the-Y (MoY) orchestrates male sex determination in major agricultural fruit fly pests. Science 2019, 365, 1457-1460. [CrossRef]

22. Traut, W.; Sahara, K.; Marec, F. Sex chromosomes and sex determination in Lepidoptera. Sex. Dev. 2007, 1, 332-346. [CrossRef] [PubMed]

23. Fujii, T.; Shimada, T. Sex determination in the silkworm, Bombyx mori: A female determinant on the W chromosome and the sex-determining gene cascade. Semin. Cell Dev. Biol. 2007, 18, 379-388. [CrossRef] 
24. Sakai, H.; Sumitani, M.; Chikami, Y.; Yahata, K.; Uchino, K.; Kiuchi, T.; Katsuma, S.; Aoki, F.; Sezutsu, H.; Suzuki, M.G. Transgenic expression of the piRNA-resistant masculinizer gene induces female-specific lethality and partial female-to-male sex reversal in the Silkworm, Bombyx mori. PLoS Genet. 2016, 12, e1006203. [CrossRef]

25. Sakai, H.; Sakaguchi, H.; Aoki, F.; Suzuki, M.G. Functional analysis of sex-determination genes by gene silencing with LNA-DNA gapmers in the silkworm, Bombyx mori. Mech. Dev. 2015, 137, 45-52. [CrossRef] [PubMed]

26. Suzuki, M.G.; Imanishi, S.; Dohmae, N.; Nishimura, T.; Shimada, T.; Matsumoto, S. Establishment of a novel in vivo sex-specific splicing assay system to identify a trans-acting factor that negatively regulates splicing of Bombyx mori dsx female exons. Mol. Cell Biol. 2008, 28, 333-343. [CrossRef]

27. Suzuki, M.G.; Imanishi, S.; Dohmae, N.; Asanuma, M.; Matsumoto, S. Identification of a Male-Specific RNA Binding Protein That regulates sex-specific splicing of Bmdsx by increasing RNA binding activity of BmPSI. Mol. Cell Biol. 2010, 30, 5776-5786. [CrossRef]

28. Wang, Y.; Li, J.; Wan, Q.X.; Zhao, Q.; Wang, K.X.; Zha, X.F. Spliceosomal protein gene BmSPX regulates reproductive organ development in Bombyx mori. Int. J. Mol. Sci. 2020, 21, 2579. [CrossRef]

29. Li, Z.Q.; You, L.; Yan, D.; James, A.A.; Huang, Y.P.; Tan, A.J. Bombyx mori histone methyltransferase BmAsh2 is essential for silkworm piRNA-mediated sex determination. PLoS Genet. 2018, 14, e1007245. [CrossRef] [PubMed]

30. Zhang, S.; Li, X.C. Preliminary Studies on the Genomic Bases of Polyphagy in Helicoverpa armigera. Ph.D. Dissertation, Chinese Academy of Agriculture Sciences, Beijing, China, 2018.

31. Lee, J.; Kiuchi, T.; Kawamoto, M.; Shimada, T.; Katsuma, S. Identification and functional analysis of a Masculinizer orthologue in Trilocha varians (Lepidoptera: Bombycidae). Insect Mol. Biol. 2015, 24, 561-569. [CrossRef] [PubMed]

32. Fukui, T.; Kiuchi, T.; Shoji, K.; Kawamoto, M.; Shimada, T.; Katsuma, S. In Vivo masculinizing function of the Ostrinia furnacalis Masculinizer gene. Biochem. Biophs. Res. Commun. 2018, 503, 1768-1772. [CrossRef]

33. Wang, Y.H.; Chen, X.E.; Yang, Y.; Xu, J.; Fang, G.Q.; Niu, C.Y.; Huang, Y.P.; Zhan, S. The Masc gene product controls masculinization in the black cutworm, Agrotis ipsilon. Insect Sci. 2019, 26, 1037-1044. [CrossRef] [PubMed]

34. Harvey-Samuel, T.; Norman, V.C.; Carter, R.; Lovett, E.; Alphey, L. Identification and characterization of a Masculinizer homologue in the diamondback moth, Plutella xylostella. Insect Mol. Biol. 2020, 29, 231-240. [CrossRef] [PubMed]

35. Deng, Z.Y.; Zhang, Y.K.; Zhang, M.; Huang, J.Y.; Li, C.Y.; Ni, X.Z.; Li, X.C. Characterization of the first W-specific protein-coding gene for sex identification in Helicoverpa armigera. Front. Genet. 2020, 11, 649. [CrossRef] [PubMed]

36. Zhao, X.C.; Dong, J.F.; Tang, Q.B.; Yan, Y.H.; Gelbic, I.; Van Loon, J.J.A.; Wang, C.Z. Hybridization between Helicoverpa armigera and Helicoverpa assulta (Lepidoptera: Noctuidae): Development and morphological characterization of F-1 hybrids. Bull. Entomol. Res. 2005, 95, 409-416. [CrossRef]

37. Katsuma, S.; Kiuchi, T.; Kawamoto, M.; Fujimoto, T.; Sahara, K. Unique sex determination system in the silkworm, Bombyx mori: Current status and beyond. Proc. Jpn. Acad. B Phys. 2018, 94, 205-216. [CrossRef] [PubMed]

38. Kawahara, A.Y.; Breinholt, J.W. Phylogenomics provides strong evidence for relationships of butterflies and moths. Proc. R. Soc. B Biol. Sci. 2014, 281, 1788. [CrossRef]

39. Kawahara, A.Y.; Plotkin, D.; Espeland, M.; Meusemann, K.; Toussaint, E.F.A.; Donath, A.; Gimnich, F.; Frandsen, P.B.; Zwick, A.; dos Reis, M.; et al. Phylogenomics reveals the evolutionary timing and pattern of butterflies and moths. Proc. Natl. Acad. Sci. USA 2019, 116, 22657-22663. [CrossRef]

40. Pearson, W.R. An introduction to sequence similarity ("homology") searching. Curr. Protoc. Bioinform. 2013, 42, 311-318. [CrossRef]

41. Katsuma, S.; Sugano, Y.; Kiuchi, T.; Shimada, T. Two conserved cysteine residues are required for the masculinizing activity of the Silkworm masc protein. J. Biol. Chem. 2015, 290, 26114-26124. [CrossRef]

42. Sugano, Y.; Kokusho, R.; Ueda, M.; Fujimoto, M.; Tsutsumi, N.; Shimada, T.; Kiuchi, T.; Katsuma, S. Identification of a bipartite nuclear localization signal in the silkworm Masc protein. FEBS Lett. 2016, 590, 2256-2261. [CrossRef] [PubMed]

43. Kiuchi, T.; Sugano, Y.; Shimada, T.; Katsuma, S. Two CCCH-type zinc finger domains in the Masc protein are dispensable for masculinization and dosage compensation in Bombyx mori. Insect Biochem. Mol. 2019, 104, 30-38. [CrossRef] [PubMed]

44. Zhao, Q.; Li, J.; Wen, M.Y.; Wang, H.; Wang, Y.; Wang, K.X.; Wan, Q.X.; Zha, X.F. A novel splice variant of the masculinizing gene masc with piRNA-cleavage-site defect functions in female external genital development in the Silkworm, Bombyx mori. Biomolecules 2019, 9, 318. [CrossRef]

45. Rideout, E.J.; Narsaiya, M.S.; Grewal, S.S. The sex determination gene transformer regulates male-female differences in Drosophila body size. PLoS Genet. 2015, 11, e1005683. [CrossRef]

46. Xu, J.; Chen, S.; Zeng, B.; James, A.A.; Tan, A.; Huang, Y. Bombyx mori P-element Somatic Inhibitor (BmPSI) Is a key auxiliary factor for Silkworm male sex determination. PLoS Genet. 2017, 13, e1006576. [CrossRef] [PubMed]

47. Yang, F.; Zhang, Z.; Hu, B.; Yu, Y.; Tan, A. A CCCH zinc finger gene regulates doublesex alternative splicing and male development in Bombyx mori. Insect Sci. 2020. [CrossRef] [PubMed]

48. Gopinath, G.; Arunkumar, K.P.; Mita, K.; Nagaraju, J. Role of Bmznf-2, a Bombyx mori CCCH zinc finger gene, in masculinisation and differential splicing of Bmtra-2. Insect Biochem. Mol. 2016, 75, 32-44. [CrossRef]

49. Sahara, K.; Yoshido, A.; Kawamura, N.; Ohnuma, A.; Abe, H.; Mita, K.; Oshiki, T.; Shimada, T.; Asano, S.; Bando, H.; et al $\mathrm{W}$-derived $\mathrm{BAC}$ probes as a new tool for identification of the $\mathrm{W}$ chromosome and its aberrations in Bombyx mori. Chromosoma 2003, 112, 48-55. 
50. Abe, H.; Mita, K.; Yasukochi, Y.; Oshiki, T.; Shimada, T. Retrotransposable elements on the W chromosome of the silkworm, Bombyx mori. Cytogenet. Genome Res. 2005, 110, 144-151. [CrossRef]

51. Kawaoka, S.; Kadota, K.; Arai, Y.; Suzuki, Y.; Fujii, T.; Abe, H.; Yasukochi, Y.; Mita, K.; Sugano, S.; Shimizu, K.; et al. The silkworm $\mathrm{W}$ chromosome is a source of female-enriched piRNAs. RNA 2011, 17, 2144-2151. [CrossRef]

52. Waldbauer, G.; Cohen, R.; Friedman, S. An improved procedure for laboratory rearing of the corn earworm, Heliothis zea (Lepidoptera: Noctuidae). Grea Lakes Entomol. 1984, 17, 113-118.

53. Waldbauer, G.; Friedman, S. Self-Selection of optimal diets by insects. Annu. Rev. Entomol. 1991, 36, 43-63. [CrossRef]

54. Li, X.C.; Berenbaum, M.R.; Schuler, M.A. Cytochrome P450 and actin genes expressed in Helicoverpa zea and Helicoverpa armigera: Paralogy/orthology identification, gene conversion and evolution. Insect Biochem. Mol. 2002, 32, 311-320. [CrossRef]

55. Hu, B.; Jin, J.P.; Guo, A.Y.; Zhang, H.; Luo, J.C.; Gao, G. GSDS 2.0: An upgraded gene feature visualization server. Bioinformatics 2015, 31, 1296-1297. [CrossRef] [PubMed]

56. Kumar, S.; Stecher, G.; Li, M.; Knyaz, C.; Tamura, K. MEGA X: Molecular Evolutionary Genetics Analysis across Computing Platforms. Mol. Biol. Evol. 2018, 35, 1547-1549. [CrossRef]

57. Marchler-Bauer, A.; Derbyshire, M.K.; Gonzales, N.R.; Lu, S.N.; Chitsaz, F.; Geer, L.Y.; Geer, R.C.; He, J.; Gwadz, M.; Hurwitz, D.I.; et al. CDD: NCBI's conserved domain database. Nucleic Acids Res. 2015, 43, 222-226. [CrossRef]

58. Nicholas, K.; Nicholas, H. Genedoc: A Tool for Editing and Annotating Multiple Sequence Alignments. 1997. Distributed by the authors. Available online: http://www.psc.edu/biomed/genedoc (accessed on 15 October 2006).

59. Deng, Z.Y.; Zhang, S.; Gu, S.H.; Ni, X.Z.; Zeng, W.X.; Li, X.C. Useful bicistronic reporter system for studying Poly(A) site-defining cis elements and regulation of alternative polyadenylation. Int. J. Mol. Sci. 2018, 19, 279. [CrossRef]

60. Zheng, G.; Li, C.; Zhou, H.; Li, S.; Li, G.; Xue, M. Establishment of two new cell lines from the embryonic tissue of Helicoverpa armigera (Lepidoptera: Noctuidae) and their responses to baculovirus infection. Acta Entomol. Sin. 2010, 53, 167-174.

61. Zhu, B.; Sun, X.; Nie, X.; Liang, P.; Gao, X. MicroRNA-998-3p contributes to Cry1Ac-resistance by targeting ABCC2 in lepidopteran insects. Insect Biochem. Mol. Biol. 2020, 117, 103283. [CrossRef]

62. Li, S.; Hussain, F.; Unnithan, G.C.; Dong, S.; UlAbdin, Z.; Gu, S.; Mathew, L.G.; Fabrick, J.A.; Ni, X.; Carriere, Y.; et al. A long non-coding RNA regulates cadherin transcription and susceptibility to Bt toxin Cry1Ac in pink bollworm, Pectinophora gossypiella. Pestic. Biochem. Physiol. 2019, 158, 54-60. [CrossRef]

63. Seroogy, K.; Tsuruo, Y.; Hokfelt, T.; Walsh, J.; Fahrenkrug, J.; Emson, P.C.; Goldstein, M. Further analysis of presence of peptides in dopamine neurons. Cholecystokinin, peptide histidine-isoleucine/vasoactive intestinal polypeptide and substance $\mathrm{P}$ in rat supramammillary region and mesencephalon. Exp. Brain Res. 1988, 72, 523-534. [PubMed] 